\title{
Analysing the monitoring mechanisms of the African Women's Protocol at the level of the African Union
}

\section{Ashwanee Budoo}

Programme Manager, LLM/MPhil in Human Rights and Democratisation in Africa, Centre for Human Rights, Faculty of Law, University of Pretoria, South Africa

\section{Summary}

The Protocol to the African Charter on Human and Peoples' Rights on the Rights of Women in Africa was adopted under article 66 of the African Charter on Human and Peoples' Rights to supplement the provisions on women's human rights protection of the Charter. Consequently, the African Commission on Human and Peoples' Rights and the African Court on Human and Peoples' Rights are the human rights bodies at the African Union level that are mandated to oversee the implementation of the African Women's Protocol. Until now the African Union has had three judicial and human rights institutions, namely, the African Commission, the African Court and the African Committee of Experts on the Rights and Welfare of the Child, to oversee the implementation of the human rights set out in its different treaties. To emphasise the importance of the realisation of women's human rights, the African Commission created the mechanism of the Special Rapporteur on the Rights of Women in Africa. Despite the adoption of the African Women's Protocol and the mechanism of the Special Rapporteur on the Rights of Women in Africa, violations of women's human rights across the continent remain widespread. The article's contention is that, as the African Commission has several aspects to its mandate and has to oversee all aspects of human rights in Africa, women's human rights do not receive the attention they require. The article analyses whether existing mechanisms sufficiently ensure the oversight of the Women's Protocol and proposes alternatives that the African Union may explore to do so.

* LLB (Mauritius) LLM LLD (Pretoria); Ashwanee.Budoo@up.ac.za 
Key words: African Women's Protocol; women's rights; African Commission; African Court; Special Rapporteur on the Rights of Women in Africa

\section{Introduction}

The Protocol to the African Charter on Human and Peoples' Rights on the Rights of Women in Africa ${ }^{1}$ (African Women's Protocol) was adopted to fill the gaps that existed in the framework for the protection of women's rights in Africa. ${ }^{2}$ The Women's Protocol was adopted as a special protocol to supplement the provisions of women's rights protection of the African Charter on Human and Peoples' Rights (African Charter) under article 66 of the Charter. Consequently, the African Commission on Human and Peoples' Rights (African Commission) and the African Court on Human and Peoples' Rights (African Court), which were established under article 30 of the African Charter and article 1 of the Protocol to the African Charter on the Establishment of an African Court on Human and Peoples' Rights (African Court Protocol), respectively, are the human rights bodies mandated to oversee the implementation of the African Women's Protocol.

Until now the African Union (AU) has had three judicial and human rights institutions, namely, the African Commission, the African Court and the African Committee of Experts on the Rights and Welfare of the Child (African Children's Committee), to oversee the implementation of the human rights set out in its different treaties. To emphasise the importance of the realisation of women's human rights, the African Commission created the mechanism of the Special Rapporteur on the Rights of Women in Africa during its 25th ordinary session in $1999^{3}$ to, amongst other things, 'serve as a focal point for the promotion and protection of the rights of women in Africa amongst the 11 members of the African Commission'. ${ }^{4}$

In addition to considering 2010-2020 as the African Women's Decade, the AU declared the year 2015 as the Year of Women's Empowerment and Development towards Africa's Agenda 2063, and the year 2016 as the African Year of Human Rights with Particular Focus on the Rights of Women. This demonstrates that the $A U$ is dedicated to the protection and promotion of women's human rights. However, despite the adoption of the African Women's Protocol and the mechanism of the Special Rapporteur on the Rights of Women in

$1 \quad$ Adopted on 11 July 2003, entered into force on 25 November 2005.

2 F Banda 'Protocol to the African Charter on the Rights of Women in Africa' in M Evans \& R Murray (eds) The African Charter on Human and Peoples' Rights: The system in practice, 1986-2006 (2008) 445.

3 ACHPR/res.38 (XXV).

4 Website of the African Commission, http://www.achpr.org/mechanisms/rights-ofwomen/about/ (accessed 7 August 2016). 
Africa, violations of women's human rights across the continent remain widespread. This article's contention is that, as the African Commission has several mandates and has to oversee all aspects of human rights in Africa, women's rights do not receive the attention they require. The article proposes alternative mechanisms to oversee the implementation of the African Women's Protocol.

The article generally seeks to analyse the viability of alternative mechanisms to oversee the implementation of the Women's Protocol. It first elaborates on the Protocol as an instrument for change. Second, it analyses the existing human rights mechanisms within the African Commission for the protection of women's rights with a view to highlighting the shortcomings of the existing framework. Third, it analyses the alternative frameworks that the AU could consider. Fourth, it provides conclusions and recommendations.

\section{African Women's Protocol as an instrument for change}

Without the African Women's Protocol violations of women's rights were not dealt with adequately at the institutional level, since the African Commission was not successful in making 'state parties accountable for gender-based discrimination occurring within their boundaries'. ${ }^{5}$ The drafting of the African Charter did not take into account women's rights and the challenges they face. ${ }^{6}$ For instance, several provisions of the African Charter $^{7}$ highlight the importance of traditions for African society, but there is no mention of harmful traditional practices which violate women's rights.

Analysing the African Women's Protocol, one can see why there was a need for an African document since its rights are beyond the scope of the Convention on the Elimination of All Forms of Discrimination Against Women (CEDAW), and the Women's Protocol deals with the rights of African women with 'greater specificity'. 8 The adoption of the Women's Protocol has been regarded as a 'longawaited realisation' since it took eight years for the text to be

$5 \quad$ F Banda Women, law and human rights: An African perspective (2005) 66-67.

6 As above.

7 Para 5 of the Preamble to the African Charter: 'Taking into consideration the virtues of their historical tradition and the values of African civilization which should inspire and characterise their reflection on the concept of human and peoples' rights'; art 17(3) of the African Charter: 'The promotion and protection of morals and traditional values recognised by the community shall be the duty of the state'; art 18(2) of the African Charter: 'The state shall have the duty to assist the family which is the custodian of morals and traditional values recognised by the community.'

8 F Viljoen 'An introduction to the Protocol to the African Charter on Human and Peoples' Rights on the Rights of Women in Africa' (2009) 16 Washington and Lee Journal of Civil Rights and Social Justice 21. 
'endorsed'. 9 The Women's Protocol, although not 'perfect', may be viewed as a 'bill of rights for African women', since it contains specific provisions that address the 'specific problems and issues' of women across the continent. ${ }^{10}$ The Women's Protocol 'primarily brings into the open' the African Charter's 'shrouded premise that women are included in its protective scope'. ${ }^{11}$ It brings the provisions of the CEDAW home by including specific issues African women face. ${ }^{12}$

However, despite 49 signatures and 39 ratifications of the African Women's Protocol, ${ }^{13}$ women's human rights across the continent continue to be violated. This means that the implementation of the Protocol faces challenges. The article recognises that one of the reasons for the non-realisation of the rights in the Women's Protocol might be its monitoring bodies not fulfilling their purpose.

\section{Analysing the existing mechanisms to oversee the implementation of the African Women's Protocol}

The Women's Protocol was adopted under article 66 of the African Charter to supplement the provisions of the latter regarding the protection of women's rights. Consequently, the African Commission and the African Court, the institutions responsible for the oversight of the African Charter, are also the organs responsible for overseeing the implementation of the African Women's Protocol. The African Commission has several entry points through which it can oversee the implementation of the Protocol. However, the Special Rapporteur on the Rights of Women in Africa (Special Rapporteur) serves as focal point for women's rights within the African Commission. The other institution that is responsible for interpreting matters 'arising from the application or implementation' of the Women's Protocol is the African Court. ${ }^{14}$ This section analyses how the African Court and the African Commission have contributed to overseeing the implementation of the African Women's Protocol.

\subsection{African Court}

The African Court was established under article 1 of the African Court Protocol, to 'complement the protective mandate' of the African

9 FJ Mohamed 'African Union Protocol on the Rights of Women in Africa: The SOAWR Campaign' in R Musa et al Breathing life into the African Union Protocol on Women's Rights in Africa (2006) 15.

10 As above.

11 F Viljoen International human rights law in Africa (2012) 253.

12 As above.

13 African Union 'List of countries which have signed, ratified/acceded to the Protocol to the African Charter on Human and Peoples' Rights on the Rights of Women in Africa' 7 September 2017 https://au.int/sites/default/files/treaties/7783 -sl-protocol_to_the_african_charter_on_human_and_peoples_rights_on_the_rights _of_women_in_africa.pdf (accessed 4 May 2018). 
Commission. ${ }^{15}$ Its jurisdiction comprises the African Charter and, by extension, the African Women's Protocol. Hence, being a judicial organ with binding decisions, it could be a good platform for overseeing the implementation of the Women's Protocol.

The African Court has been approached in relation to violations of the Women's Protocol but as of May 2018, only one of these cases has been decided on its merits. The case of APDF \& IHRDA $v$ Republic of Mali $^{16}$ may be considered ground-breaking since it is the first case where the African Court has found violations of the African Women's Protocol. The Court decided that several articles of the Persons and Family Code of Mali were in contravention of the African Women's Protocol. These articles provide for the minimum age of marriage to be below 18; there is no verification of parties' consent to marriage; and unequal inheritance for women. These provisions further led to the conclusion that Mali does not respect the obligation to eliminate practices or traditions that are harmful to women and children. The Court ordered Mali to amend its Persons and Family Code to ensure that it abides by its obligations under international law, including under the African Women's Protocol. This case is the only case at the AU level in which violations of the Women's Protocol have been found. Hence, it may safely be concluded that if all the preliminary conditions are met, the African Court would not hesitate to decide against a country on issues that concern the Women's Protocol.

Nevertheless, in most cases applicants find it difficult to satisfy the admissibility requirements, and cases are dismissed without them being considered on the merits. For instance, in the case of Mariam Kouma \& Another $v$ Republic of Mali, ${ }^{17}$ where the applicants had alleged violations of several articles of the African Women's Protocol, although the Court admitted that it has jurisdiction, the case was held inadmissible on the basis of non-exhaustion of local remedies. Additionally, in an advisory opinion concerning article $6(d)$ of the African Women's Protocol, the African Court held that it could not give the opinion requested since the case was not brought by institutions recognised by the $\mathrm{AU} .^{18}$

As noted, the African Court's accessibility conditions make it difficult for human rights activists to use it as a platform for overseeing the implementation of the African Women's Protocol. First, a state has to make a declaration under article 34(6) of the African Court

\footnotetext{
15 Art 2 African Court Protocol.

16 Association pour le progrès et la défense des droits des femmes Maliennes (APDF) and the Institute for Human Rights and Development in Africa (IHRDA) v Republic of Mali Application 46/2016 11 May 2018.

17 Application 40/2016 21 March 2018.

18 Request for Advisory Opinion by the Centre for Human Rights \& Others 001/2016 28 September 2017.
} 
Protocol $^{19}$ for non-governmental organisations (NGOs) to bring a case against it. ${ }^{20}$ As of 15 June 2017 , only seven countries have made such a declaration, ${ }^{21}$ including Mali, which explains why the applicants were able to approach the Court in the case of APDF \& IHRDA $\vee$ Mali. The small number of declarations made under article 34(6) of the African Court Protocol demonstrates that African countries are fearful of giving NGOs the opportunity to hold them accountable for any human rights violation.

Second, there are many barriers to accessing the African Court. The advisory opinions submitted by the Socio-Economic Rights and Accountability Project ${ }^{22}$ and the Centre for Human Rights ${ }^{23}$ are indicative of the barriers to accessing the African Court since there are but a few selected NGOs that are recognised by the AU itself, and not by any of its organs.

Therefore, although the African Court could be a good avenue to hold state parties accountable for women's rights violations, its accessibility criteria might act as a challenge. As such, despite the fact that the African Court has proved itself worthy of making a decision concerning violations of the African Women's Protocol, such a positive stride might be repeated any time soon.

\subsection{African Commission}

The African Commission was established under article 30 of the African Charter. The Commission has various mandates and functions, one of which is to 'ensure the protection of human and peoples' rights under conditions laid' under the African Charter and, by extension, under the African Women's Protocol. This section analyses the role of the African Commission in overseeing the implementation of the Women's Protocol through, first, the mechanism of the Special Rapporteur and, second, the communication procedure.

19 Art 34(6) of the African Court Protocol: 'At the time of the ratification of this Protocol or any time thereafter, the state shall make a declaration accepting the competence of the Court to receive cases under article 5(3) of this Protocol. The Court shall not receive any petition under article 5(3) involving a state party which has not made such a declaration.'

20 Art 5(3) of the African Court Protocol: 'The Court may entitle relevant nongovernmental organisations (NGOs) with observer status before the Commission, and individuals to institute cases directly before it, in accordance with article 34(6) of this Protocol.'

21 African Union 'List of countries that have signed, ratified/acceded to the Protocol to the African Charter on Human and Peoples' Rights on the Establishment of an African Court on Human and Peoples' Rights' 15 June 2017 https://www.au.int/ web/sites/default/files/treaties/7778-sl-protocol_to_the_african_charter_on_hum an_and_peoplesrights_on_the_estab.pdf (accessed 28 June 2017).

22 African Court Request for Advisory Opinion by the Socio-Economic Rights and Accountability Project 001/2013 26 May 2017 http://en.african-court.org/images/ Cases/Advisory\%20Opinion/Advisory\%20Opinions/Request\%20for\%20Advisory\% 200pinion\%20No.001-2013-Socio-\%20Economic\%20Rights\%20and\%20Accou ntability\%20Project\%20(SERAP)\%20ENGLISH\%20(2).pdf (accessed 27 June 2017).

23 Centre for Human Rights \& Others (n 17 above). 


\subsubsection{Special Rapporteur on the Rights of Women in Africa}

The African Commission established the mechanism of the Special Rapporteur in 1999 to ensure that women's human rights receive sufficient attention while exercising its functions under article 45(1)(a) of the African Commission. ${ }^{24}$ The mechanism of the Special Rapporteur was the first mechanism created by the African Commission to 'place particular emphasis on the problems and rights specific to women in Africa'. ${ }^{25}$

The mechanism of the Special Rapporteur has several mandates, which are $\mathrm{a}^{26}$ to 'serve as a focal point for the promotion and protection of the rights of women in Africa amongst the 11 members of the African Commission'; to 'assist African governments in the development and implementation of their policies of promotion and protection of the rights of women in Africa, particularly in line with the domestication' of the African Women's Protocol and 'the general harmonisation of national legislation to the rights guaranteed' therein; to 'undertake promotional and fact-finding missions' in African countries $^{27}$ to 'disseminate' the provisions of the African Women's Protocol and to 'investigate on the situation of women's rights'; to follow up the implementation of the African Women's Protocol; to 'draft resolutions on the situation on women in the various African countries'; to 'carry a comparative study' on women's human rights situations in different African countries'; to 'define guidelines for state reporting' under the African Women's Protocol'; and to collaborate with other relevant stakeholders in the protection and promotion of women's human rights.

Since the article critically analyses the existing mechanisms to oversee the implementation of the African Women's Protocol, the following paragraphs demonstrate the challenges that the mechanism of the Special Rapporteur faces in the exercise of its mandates. These challenges are the basis for the motivation of alternatives to oversee the implementation of the Women's Protocol.

\section{Fact-finding or promotional missions}

As a commissioner of the African Commission, the Special Rapporteur usually takes part in the fact-finding or promotion missions of the African Commission without undertaking the mission on its own. For

24 African Commission 'Resolution on the Designation of the Special Rapporteur on the Rights of Women in Africa' ACHPR/res.38 (XXV) 99 (1999) para 4: 'Referring to the provisions of article 45(1)(a) of the African Charter on Human and Peoples' Rights'.

25 Website of the African Commission, http://www.achpr.org/mechanisms/rights-ofwomen/ (accessed 4 May 2018).

26 Website of the African Commission, http://www.achpr.org/mechanisms/rights-ofwomen/about/ (accessed 2 October 2016).

27 See the activity reports of the Special Rapporteur for information about the missions undertaken http://www.achpr.org/mechanisms/rights-of-women/ (accessed 17 March 2016). 
instance, during the 60th ordinary session of the African Commission (held from 8 to 22 May in Niger), on 10 May the Special Rapporteur, in collaboration with the Centre for Human Rights, had an advocacy meeting with relevant government stakeholders from Niger concerning the ratification of the African Women's Protocol. ${ }^{28}$ Moreover, from 13 to 18 January 2014 the Special Rapporteur took part in a promotion mission to the Gabonese Republic with another commissioner of the African Commission. ${ }^{29}$ The objectives of this mission, amongst others, were to promote the African Women's Protocol and to gather information on the situation of women in the country. ${ }^{30}$ The mission discussed in depth the issue of women's human rights with different stakeholders. However, the discussion is centred on women's rights only when the Special Rapporteur accompanies the delegation or when the objective of the mission is to promote the African Women's Protocol. For instance, during the mission to Uganda in 2013 by commissioners of the African Commission, despite the fact that a meeting was held with the Minister of Gender, Labour and Development, ${ }^{31}$ the discussions were very shallow compared to the mission in Gabon. Since there was a need to meet several stakeholders in different areas in the promotion mission to Uganda, the focus could not be on women's rights. Similarly, during the promotion mission to the Republic of the Seychelles, although the commissioner undertaking the mission did meet with stakeholders working on women's rights, the focus was shared since the mission had to consult with stakeholders working in other areas of human rights as well. ${ }^{32}$

This article's contention is that the Special Rapporteur forms part of the African Commission which is responsible for a whole range of human rights contained in the African Charter, in addition to the African Women's Protocol. Consequently, the missions of the African Commission have to be balanced and have to cover all the human rights that it is responsible for. Even when the Special Rapporteur is part of a mission, she cannot fully investigate the implementation of the African Women's Protocol since there is a need to assess the implementation of other rights in the African Charter. As a result, the focus is shared. Such a situation would not arise if, similar to the

28 On file with author.

29 Website of the African Commission, http://www.achpr.org/mission-reports/ (accessed 2 October 2016).

30 African Commission 'Report of the human rights promotion mission to the Gabonese Republic 13-18 January 2014' para 5 http://www.achpr.org/files/ses sions/54th/mission-reports/gabon-promo-2014/achpr54os_misrep_promo_gabon 2014_eng.pdf (accessed 2 October 2016).

31 African Commission 'Report of the joint promotion mission undertaken to the Republic of Uganda 25-30 August 2013' paras 62-79.

32 See generally African Commission 'Report of the human rights promotion mission to the Republic of Seychelles 6-10 April 2016' http://www.achpr.org/files/news/ 2016/09/d231/report_of_achpr_promotion_mission_to_seychelles_6_10_april_ 2015.pdf (accessed 2 October 2016). 
CEDAW Committee or the African Children's Committee, ${ }^{33}$ there was a human rights institution at the AU level which would focus solely on the implementation of the African Women's Protocol. Such an institution could undertake missions on different areas of women's human rights to have a more comprehensive understanding of the implementation of those particular rights compared to the African Commission's missions, which only provide for an overview of certain rights protected by the African Women's Protocol.

\section{Guidelines on state reporting}

The state reporting procedure is an important component of the implementation of the African Women's Protocol since it 'serves as a forum for constructive dialogue' and allows the African Commission to 'monitor' the implementation of the document in question and to 'identify the challenges' that the country faces in the implementation of the provisions therein. ${ }^{34}$ The state reporting procedure offers states the opportunity to keep up to date with the steps they have taken in the implementation of the African Women's Protocol. As such, it acts as an incentive for states to implement the provisions of the Women's Protocol so as not to be shamed by the African Commission in its Concluding Observations.

In line with its mandate, the Special Rapporteur in 2009 prompted the African Commission to issue guidelines on state reporting under the African Women's Protocol. These guidelines direct states on how to prepare their state reports taking into account the African Women's Protocol. Twenty-eight countries have since 2009 submitted state reports to the Commission, 35 and 18 of these had ratified the African Women's Protocol at the time of the submission. ${ }^{36}$ However, of these 18 countries, only seven have prepared their state reports while making reference to the guidelines on state reporting under the African Women's Protocol. ${ }^{3}$

The Special Rapporteur has been emphasising the guidelines on state reporting by jointly holding a side session with the Centre for Human Rights, University of Pretoria, on the topic during the ordinary sessions of the African Commission. However, such sessions last only one hour. Moreover, the Special Rapporteur has supported initiatives by the Centre for Human Rights to train government officials on the

33 Website of the African Children's Committee http://www.acerwc.org/ investigation/missions-reports/ (accessed 28 June 2017): The African Children's Committee has undertaken two advocacy missions to South Sudan and Central African Republic respectively in 2014.

34 Website of the African Commission http://www.achpr.org/states/ (accessed 2 October 2016).

35 Website of the African Commission http://www.achpr.org/states/reports-andconcluding-observations/ (accessed 28 June 2017).

36 Website of the African Commission http://www.achpr.org/instruments/womenprotocol/ratification/ (accessed 28 June 2017).

37 The author analysed the state reports submitted. 
state reporting guidelines under the African Women's Protocol, and the reports that have been prepared according to the guidelines are from countries whose officials have attended the training.

The above demonstrates that if there is in-depth engagement with states on the state reporting guidelines under the African Women's Protocol, these guidelines might be followed during the preparation of state reports. The Special Rapporteur has to rely on civil society organisations (CSOs) to popularise these guidelines.

\section{Investigations, studies and research}

Article 45(1)(a) of the African Charter provides that the African Commission has the following function:

to collect documents, undertake studies and researches on African problems in the field of human and peoples' rights, organise seminars, symposia and conferences, disseminate information, encourage national and local institutions concerned with human and peoples' rights, and should the case arise, give its views or make recommendations to governments.

As such, the African Commission has to undertake studies and research in the area of human rights. For instance, during the 16th extraordinary session of the African Commission, a resolution was passed to the effect that a study would be conducted by the African Commission on child marriage, the report of which would be adopted during its 57 th ordinary session. ${ }^{38}$

Moreover, the African Commission can carry out investigations under article 46 of the African Charter. The African Charter does not define the scope and different methods of investigation. ${ }^{39}$ However, the Rules of Procedure of the African Commission adopted in 2010 (Rules of Procedure) state that the African Commission may invite 'specialised agencies, intergovernmental organisations and United Nations bodies' to 'submit reports on the implementation of the African Charter in areas of common concern'. 40 However, since the adoption of the Rules, the African Commission has not undertaken any investigation under the African Women's Protocol.

The Special Rapporteur, being the focal point for women's rights in the African Commission, has pushed for the adoption of a resolution for the study on child marriages. Since the African Commission already has many other mandates, it is difficult for it to focus its resources on investigations, research and studies that focus only on women's human rights.

38 African Commission 'Resolution on the need to conduct a study on child marriage in Africa' adopted during the 16th extraordinary session of the African Commission 20-29 July 2014.

39 CA Odinkalu \& C Christensen 'The African Commission on Human and Peoples' Rights: The development of its non-state communication procedures' (1998) 20 Human Rights Quarterly 2242. 


\section{Resolutions, General Comments and guidelines}

Article $45(1)(b)$ of the African Charter mandates the African Commission to 'formulate and lay down, principles and rules aimed at solving legal problems relating to human and peoples' rights and fundamental freedoms upon which African governments may base their legislations'. The African Commission has executed this mandate by adopting guidelines, resolutions and General Comments on different human rights issues, including women's human rights.

The African Commission, with the motivation of the Special Rapporteur and with the support of the Centre for Human Rights, 'proactively' 41 issued General Comments on articles $14(1)(d)$ and (e) of the African Women's Protocol in 2012 (General Comment 1) under article 45(1)(b) of the African Charter. These General Comments are intended to be 'used by human rights treaty bodies to interpret the provisions of relevant international legal instruments, with a view to assisting states to fulfil their obligations under such instruments' ${ }^{42}$ Furthermore, the African Commission adopted a General Comment on articles 14(1)(a), (b), (c) and (f) and articles 14(2)(a) and (c) of the African Women's Protocol in 2014, again through the Special Rapporteur and with the support of IPAS Africa Alliance, an NGO. ${ }^{4}$

In addition to the above two General Comments under article 14 of the African Women's Protocol, the African Commission and the African Children's Committee in 2017 jointly adopted a General Comment under article 6(b) of the African Women's Protocol and under article 21(2) of the African Children's Charter on ending child marriage. ${ }^{44}$ This process was spearheaded by the Special Rapporteur with the technical support of the Centre for Human Rights.

The above General Comments of the African Commission were all spearheaded by the Special Rapporteur and had the technical assistance of NGOs. Although one might say that the adoption of the three General Comments represents a milestone in the protection and promotion of women's human rights, this article contends that on a continent where women's rights violations are so widespread, there is a need for more guidance to as to how states can implement the provisions of the African Women's Protocol.

41 R Murray \& D Long The implementation of the findings of the African Commission on Human and Peoples' Rights (2015) 67.

42 General Comments on arts $14(1)(d)$ and (e) of the African Women's Protocol para 1 .

43 Preface to General Comment 2 http://www.achpr.org/files/instruments/generalcomments-rights-women/achpr_instr_general_comment2_rights_of_women_in_ africa_eng.pdf (accessed 28 June 2017).

44 General Comment on child marriage http://www.achpr.org/files/news/2018/01/ d321/joint_gc_acerwc_achpr_ending_child_marriage_eng.pdf (accessed 4 May 2018). 


\subsubsection{Communication procedure}

The African Commission is mandated to receive cases relating to violations of the provisions of the African Charter ${ }^{45}$ and, by extension, those of the African Women's Protocol since the African Women's Protocol was adopted as a supplement to the African Charter.

An analysis of a database of the African Commission's cases demonstrates that the Commission has dealt with women's rights issues. For instance, the Commission has used article 18(3) of the African Charter to find a violation of women's human rights in the case of Egyptian Initiative for Personal Rights \& Interights V Egypt II in 2011. ${ }^{46}$ However, Egypt had not yet ratified the African Women's Protocol and although the incidents happened after the entering into force of the instrument, the complainants could not refer to the document. Moreover, the coming into force of the Protocol might have motivated the decision of the African Commission.

Nevertheless, unlike the African Court, the African Commission has not yet decided a case concerning the violation of a right protected by the African Women's Protocol. This may have been due to the wide mandate of the African Commission which tends to overshadow women's human rights.

\section{Proposed reforms at the African Union level}

The above section has demonstrated that the overseeing mechanisms at the $\mathrm{AU}$ level have undertaken steps to ensure that the rights in the African Women's Protocol are implemented. Nevertheless, despite strides towards the promotion and protection of human rights, the AU still has to take steps to ensure that its mechanisms optimally warrant that the rights in the African Women's Protocol are realised. There is thus a need for reforms at the AU Union level that would accelerate the protection and promotion of women's rights.

\subsection{Creation of a new institution to oversee the implementation of the African Women's Protocol}

The African Commission faces challenges in overseeing the African Women's Protocol since it has several other functions that shift its focus from women's rights. One proposed reform could be the creation of another institution that oversees the implementation of the Women's Protocol. The creation of such an institution will ensure that the AU has one specific institution focusing solely on the Women's Protocol, thereby ensuring that women's human rights across the continent receive the attention they deserve. The inspiration for the

45 Arts 47-59 of the African Charter: In the event a state has violated the provisions of the African Charter, another state or individuals or organisations can submit a communication to the African Charter alleging such violations. 
creation of such an institution comes from, first, the CEDAW Committee and, second, the fact that there already is an institution at the AU level that focuses on one particular vulnerable group, namely, children. Therefore, the institution proposed to be established could be inspired by a combined institutional structure of the CEDAW Committee and the African Children's Committee. However, the creation of the proposed institution would need a legal basis, and this can be achieved either by the adoption of a new protocol to the African Charter which establishes the proposed institution, or by amending the African Women's Protocol.

As discussed above, article 66 of the African Charter provides for the adoption of special protocols to supplement its provisions. One possible means of providing the legal basis for the creation of the proposed institution could be the adoption of a new protocol under article 66 of the African Charter. This would not be the first time that the $\mathrm{AU}$ would be using article 66 of the African Charter to adopt a protocol to create an institution. The African Court Protocol was adopted under article 66 setting up the African Court, hence confirming that an institution to oversee the African Charter could be created using the same article. However, this article's contention is that the process of the adoption of a new treaty to establish an institution might be too lengthy and might require too many resources since it requires discussions before the adoption and it might take time for states to ratify it. ${ }^{47}$ It might face the same situation as the African Court Protocol, and the procedure may take more than ten years, which is too long, taking into consideration that there are urgent women's rights issues that need to be addressed on the continent.

Another way of providing the legal basis for the proposed institution is through the amendment of the African Women's Protocol by following the steps provided by article 30 of the Women's Protocol. In such a situation, a state party must submit a written proposal for the amendment of the African Women's Protocol to the Chairperson of the AU Commission. ${ }^{48}$ Thereafter, the AU Commission has to transmit the written proposal to the other state parties who, in the form of the Assembly, will review the proposal within one year of submission. ${ }^{49}$ The amendment to include the creation of the proposed institution could be adopted by a simple majority and it would come into force 30 days after the Chairperson of the AU Commission receives the notice of the vote. ${ }^{50}$

\footnotetext{
47 Website of the African Court http://en.african-court.org/index.php/about-us/ establishment (accessed on 27 June 2017). The African Court Protocol was adopted on 9 June 1998 and came into force only on 25 January 2004.

48 Arts 30(1) \& (2) African Women's Protocol.

49 Arts 30(2) \& (3) African Women's Protocol.

50 Arts 30(4) \& (5) African Women's Protocol.
} 
Once the amendment has been effected, the AU could seek funding from either states or international partners to set up the proposed institution. Inspired by the African Children's Committee, this institution may be called the African Committee of Experts on the Rights of Women in Africa. This procedure should involve consultations with states, the African Commission, more specifically the Special Rapporteur, the African Children's Committee, members of the CEDAW Committee, and experts and NGOs working in the area of women's human rights.

However, the creation of such an institution is not without challenges. The fact that the AU has not considered the creation of an institution that has women's rights as focus indicates that this step faces challenges. The most obvious challenge hindering the creation of an institution to oversee the implementation of the African Women's Protocol is a lack of resources. An institution focusing on the implementation of the Women's Protocol at the AU level would require substantial resources for its functioning, and this may be a deterrent factor. For instance, the budget of the African Commission for the year 2017 is US \$5 525705 , whereas that of the African Children's Committee is US $\$ 827556 .^{51}$

Since the proposed institution would be modelled on the African Children's Committee, its budget would be similar, which represents about one-sixth of the budget of the African Commission. A logical solution to find the resources for the new institution would be to divert one-sixth of the African Commission's budget to it. However, it is doubtful that within the African Commission, the budget dedicated to women's human rights is that figure, given the panoply of rights the African Commission has to deal with. Therefore, even if there were the creation of a new institution which would oversee the implementation of the African Women's Protocol, the budget of the African Commission would not substantially decrease and there will be a need to raise additional funds.

This lack of financial resources may be the greatest challenge in the creation of a new institution for the implementation of the African Women's Protocol since, as it is, the AU has to rely on its international partners to support the largest part of its budget. The creation of a new institution to oversee the implementation of the African Women's Protocol would imply seeking more financial support from international partners, and this would be dependent upon whether such support would be available.

However, this article's contention is that, given the focus on women's human rights in the contemporary world, the AU must be motivated to raise funds towards the creation of an institution which would oversee the implementation of the African Women's Protocol.

51 African Union 'Decision on the budget of the African Union for the 2017 financial year' adopted during the 29th ordinary session of the Executive Council 13-15 July 2016 EX.CL/Dec.919(XXIX) 2. 
The Women's Protocol has been regarded as an instrument of change in the women's human rights landscape across the continent, and it would be futile to have such a document if the rights therein are not fully realised. Although there have been strides towards the protection of women's human rights, progress is very slow. To speed up the implementation of the African Women's Protocol, the AU might consider the setting up of an additional institution and must be dedicated to raise funding from either states or from international partners.

\subsection{Reinforcing existing mechanisms}

The African Women's Protocol was 'needed' since there had been 'insufficient attention' paid to existing women's rights standards on the continent. ${ }^{52}$ The proposal to have an additional instrument to regulate women's rights across the continent faced some resistance. ${ }^{53}$ It was argued that the African Charter already contains provisions which, if subjected to a 'progressive and expansive interpretive approach', will ensure that women's rights in Africa are protected. ${ }^{54}$ The discussion about a new instrument for women's rights in Africa faced challenges because the existing norms had not been exploited to its full: '[T]he normative and institutional potential of the existing system should be used to its full potential. ${ }^{155}$

A parallel may be drawn between arguments against the adoption of the African Women's Protocol and for the reinforcement of existing mechanisms at the AU level to ensure its implementation. The African Commission and, specifically, the mechanism of the Special Rapporteur, have not been given the opportunity to fully execute their mandate. The AU could reinforce its existing mechanisms. For instance, the mechanism of the Special Rapporteur could be reviewed to ensure that it operates to its maximum. As indicated above, the Special Rapporteur has limited resources in terms of time and personnel and, hence, cannot fulfil its mandate to the optimum. The $\mathrm{AU}$ needs to enhance the support it provides to the mechanism of the Special Rapporteur to ensure that the mechanism has the required tools to oversee the implementation of the African Women's Protocol.

\subsection{Creation of working groups/independent experts/additional special rapporteurs}

Similar to the Special Rapporteur, the African Commission has established several other mechanisms to ensure that human rights across the continent are realised. One of these mechanisms are 
Working Groups on different human rights issues. ${ }^{56}$ At the moment the Special Rapporteur is the only special mechanism that has as its sole focus the implementation of the African Women's Protocol, even if other mechanisms deal with issues affecting women. The Special Rapporteur usually is only one person and, hence, there is a constraint in terms of human resources. The creation of a Working Group on the Rights of Women at the African Commission level would ensure that the oversight of the African Women's Protocol is not left to only one person who has limited time, but instead to a group of persons who would have more resources to deal with women's rights.

As discussed above, the African Commission and the Special Rapporteur have limited resources to undertake country visits and, therefore, they cannot fully realise their promotional mandates. The $\mathrm{AU}$ has recognised this challenge and in 2014 established the mechanism of the Special Rapporteur on Child Marriage that focuses on issues affecting the girl child. ${ }^{57}$ The Special Rapporteur on Child Marriage has been working in collaboration with the Special Rapporteur on the Rights of Women on child marriage issues. Similar to the mechanism of the Special Rapporteur on Child Marriage, the $\mathrm{AU}$ can consider the appointment of additional special rapporteurs that deal with issues that gravely affect women across the continent.

Moreover, at the United Nations level, there are independent experts that are mandated to 'report and advise on human rights from a thematic or country-specific perspective' ${ }^{58}$ The African Commission could be inspired by this practice and set up independent experts responsible for a particular country or theme. The creation of independent experts at the African Commission level would ensure that sufficient time and resources are dedicated to a specific women's rights issue or country. The independent experts can each be responsible for one topic that affects women's rights and can approach donors to fund their mandates.

\section{Conclusion}

The article sought to assess whether the existing mechanisms at the $\mathrm{AU}$ level are sufficient to ensure the proper implementation of the African Women's Protocol. It first demonstrated how the African Women's Protocol was adopted as an instrument for change regarding women's human rights in Africa. It then pointed out that despite the presence of the African Women's Protocol, women's rights across the continent continue to be violated. The article then

56 Website of the African Commission http://www.achpr.org/mechanisms/ (accessed 7 May 2018).

57 Website of the African Union https://au.int/en/newsevents/28021/appointmentspecial-rapporteur-child-marriage (accessed 21 May 2018).

58 Website of the United Nations http://www.ohchr.org/EN/HRBodies/SP/Pages/ Welcomepage.aspx (accessed 7 May 2018). 
suggested that the reasons for the continued violations could be linked to the fact that the existing mechanisms do not fully focus on the implementation of the Women's Protocol due to resources constraints. This section demonstrated that, despite the presence of the mechanism of the Special Rapporteur and the will to ensure the implementation of the African Women's Protocol, the existing institutions have a panoply of rights to focus on and face challenges in the form of their accessibility. It then proposed alternatives in the form of the creation of a new institution, the reinforcement of existing mechanisms, and the creation of working groups/independent experts/additional special rapporteurs that the AU could consider for overseeing the implementation of the African Women's Protocol.

However appealing these alternatives seem, one needs to bear in mind that they would also require resources, be it financial, human or in terms of time, on the part of the AU. Nevertheless, the AU has committed itself to ensure that women's rights across the continent are realised, and it is now time to take further steps towards that goal. Despite the fact that some progress has been made in this field, much still needs to be done, and the AU needs to review its existing modus operandi with a view to ensuring that state parties implement the rights set out in the African Women's Protocol.

Realising women's rights across the continent will also need the full support of civil society organisations. As of now, civil society organisations have provided full support to the AU towards the implementation of the rights set out in the African Women's Protocol. It is recommended that the $\mathrm{AU}$ deepens its partnership with civil society organisations and consults them on the way forward. 